\title{
The shift from class-based to online learning during COVID-19: A student and academic perception
}

\author{
Nicolette Sammut Bartolo (D), Maresca Attard Pizzuto (D), Francesca Wirth (DD , Janis Vella Szijj (D), \\ Anthony Serracino-Inglott (iD, Lilian M. Azzopardi (iD
}

Department of Pharmacy, Faculty of Medicine and Surgery, University of Malta, Malta

\author{
Keywords \\ Online learning \\ Pharmacy Academics \\ Pharmacy Students \\ Resources \\ Psychological Effects
}

\section{Correspondence}

Nicolette Sammut Bartolo

Department of Pharmacy

Faculty of Medicine and Surgery

University of Malta

Msida

Malta

nicolette.sammut-bartolo@um.edu.mt

\begin{abstract}
The COVID-19 pandemic, which was globally declared during the first quarter of the year 2020, led to the transition of teaching activities from the traditional classroom setting to online platforms. This study evaluated preparedness and perception towards online learning and its impact among pharmacy academics and students by using two self-administered questionnaires. Fifteen academics and 60 students answered the questionnaire. Participants had the required technology for online learning (academics $n=$ $14,93 \%$; students $n=56,93 \%$ ) and believed that the transition to online learning was easy (academics $n=12,80 \%$; students $n=41,68 \%$ ). Most participants (academics $n=12,80 \%$; students $n=46,77 \%$ ) stated that online learning allowed more flexibility even though they preferred classroom-based approach. A minority of students stated that the shift to online learning during the pandemic made them feel alone $(n=11,18 \%)$, anxious $(n=7,12 \%)$ and depressed $(n=9,15 \%)$. Given the option, participants would prefer a hybrid learning approach, whereby some teaching activities are switched to online platforms.
\end{abstract}

\section{Introduction}

Online learning has been applied to teaching of various pharmacy-related and medical-related courses (Jenkins, Goel, \& Morrell, 2008; Crouch, 2009; Gray \& Tobin, 2010; Yeh et al., 2014; Morton et al., 2016; Lean et al., 2020). Online learning can provide advantages, such as a more student-focused approach, flexibility and enticement of students to delve more into subjects (McFarlin, 2008; Kabassi et al., 2016; Herbert et al., 2017). However, the implementation of online learning may make the student feel lonely and may affect self-confidence (Kahl \& Cropley, 1986; Herbert et al., 2017).
The COVID-19 pandemic, which was globally declared during the first quarter of the year 2020, led to the transition of teaching activities from the traditional classroom setting to online platforms. Remote learning was adopted by the University of Malta as of March 2020, as a measure to control the spread of the virus. Due to the close proximity of the University of Malta to the island's acute general hospital, areas of the Medical School, of which the Department of Pharmacy forms part, and the University of Malta campus were converted into temporary hospital wards as preparation measures to address the needs which may arise due to the pandemic (Grech \& Attard-Montalto, 2020). 
Online teaching activities were carried out using different platforms, including WebEx, Zoom and Panopto. The remote learning shift consisted of lectures and a number of tutorials and recitations that are practice-based or intended to develop practice research skills and are carried out as small group teaching.

The shifting from the traditional teaching model of a classroom-based setting to an online setting may have an impact on students and academics. This study aimed to evaluate the perception of students and academics of the Department of Pharmacy at the University of Malta regarding the shift undertaken from classroom-based learning to remote teaching.

\section{Method}

Two self-administered questionnaires were developed to evaluate the perception of pharmacy students and academics about the shift towards remote teaching. The questionnaires were developed by the authors and validated by four academic pharmacists using the Delphi technique. Participants were requested to rate statements related to online learning and the psychological effect of delivering and attending online learning activities using a five point Likert scale, where 1 corresponded to 'Strongly Disagree' and 5 corresponded to 'Strongly Agree'. The statement rated the need to purchase new technology and install or upgrade the internet service, the ease of adjusting to online teaching and learning, and whether the support and guidelines provided by the University of Malta were sufficient. Participants were asked to rate whether the period allocated for the transition was adequate and how their workload was affected. Participants were asked about their willingness to continue remote teaching and learning in the future, by switching all activities online or by adopting a hybrid approach. The questionnaire assessed whether the available online platforms were easy to use.

Ethics approval was obtained from the Faculty Research Ethics Committee of the University of Malta. Questionnaires were disseminated online to all academics and students of the Department of Pharmacy at the University of Malta, using Google Forms. Quantitative data analysis was performed using SPSS v.26.

\section{Results}

\section{Participants' demographics}

A total of 15 academics and 60 pharmacy students answered the questionnaire. The age of the academics ranged between 27 to 60 years, where five (33.3\%) participants were 30 years old or under, five (33.3\%) participants were between 51 and 60 years old, followed by $31-40$ years $(n=2,13.3 \%)$ and $41-50$ years $(n=2,13.3 \%)$. One $(7 \%)$ respondent did not disclose the age. Ten (67\%) academics were female and 5 (33\%) were male. Six (40\%) academics had less than five years experience, six (40\%) had over 20 years of experience, followed by $11-15$ years $(n=2,13 \%)$ and 16 to 20 years $(n=1,7 \%)$.

Of the 60 students participating in the study, 35 (58\%) students were 21 to 30 years old, followed by $\leq 20$ years $(n=13,21 \%), 31-40$ years $(n=4,7 \%)$ and $41-50$ years $(n=4$, $7 \%)$. Four (7\%) did not disclose their age. Forty-two (70\%) students were female. The majority of the students $(n=30$, $50 \%$ ) were enrolled in the undergraduate Bachelor of Science in Pharmaceutical Science programme (first year $n=6$; second year $n=4$; third year $n=9$; fourth year $n=11$ ) which is the first cycle degree required for a Master of Pharmacy. Seven $(n=12 \%)$ students were reading for a Bachelor of Science in Pharmaceutical Technology (first year $n=1$; second year $n=3$, third year $n=2$; undisclosed $\mathrm{n}=1)$. Six (10\%) students were enrolled for the Master of Pharmacy degree and six (10\%) in the Master of Science in Pharmaceutical and Regulatory Sciences programme. While 11 (18\%) were reading for a level 8 Doctorate in Pharmacy, with six students being in the first year of the programme, two in second year and three in third year.

\section{Shifting to online learning}

When academics were asked if they needed to purchase a technological device for online teaching, one (7\%) answered in the affirmative. None of the academics required the installation or an upgrade of internet services and $13(87 \%)$ academics strongly agreed/agreed that they had the necessary technology to set up for online teaching.

Four (7\%) students stated that they needed to purchase a technological device to be able to follow online learning activities. Nine (15\%) students strongly agreed/agreed that they needed to install or upgrade their internet service to be able to follow online learning activities and $48(80 \%)$ stated that they had the necessary technology to follow lectures online.

Academics found it easy to adjust to online teaching ( $n=12,80 \%$ ) and the period allocated for the transition was sufficient $(n=12,80 \%)$. Academics agreed/strongly agreed that the support provided by the administration staff $(n=14,93 \%)$ and fellow academics $(n=11,73 \%)$ was adequate. Guidelines provided by the University of Malta about how to conduct online teaching were found to be 
sufficient ( $n=13,87 \%)$. Five (33\%) academics found that the shift from classroom-based to online teaching increased their workload, while eight (53\%) strongly disagreed/disagreed with the statement.

Forty-one (68\%) students stated that they found it easy to adjust to online learning, while nine (15\%) gave a neutral response. Thirty-nine (65\%) students stated that the support provided by the administrative and academic staff ( $n=36,60 \%$ ) to transition to online learning was adequate, while 13 (22\%) gave a neutral response.

\section{Ease of using platforms applied for online learning}

The three main platforms used for online learning were Zoom ( $n=13,87 \%)$, Google Meet $(n=9,60 \%)$ and Panopto $(n=5,33 \%)$. Other platforms used included Microsoft Teams $(n=3,20 \%)$ and Skype $(n=1,7 \%)$. Teaching provided by academic staff from other servicing departments used PowerPoint presentations with a recorded audio uploaded on the University's Virtual Learning Environment $(n=1,7 \%)$.

Academics and students were asked to rate how easy it was to use the platforms for online learning (Table I). When asked to comment about the platforms used for online learning, three (20\%) academics commented that they made use of Microsoft Teams and that it was a good platform for remote teaching. Students commented that they made use of Skype as a platform for online learning activities and was rated as being very easy and easy to use by 20 (33\%) participants, while 18 (30\%) were neutral. Students were asked which type of technology they used to follow online learning. Forty-nine (82\%) students used a laptop, followed by a desktop computer ( $n=5,8 \%$ ), smartphone $(n=5,8 \%)$ and Tablet $(n=1,2 \%)$.

Table I: Rating of the ease of use of the provided online platforms

\begin{tabular}{lll}
\hline & Academics $(\mathbf{N}=\mathbf{1 5})$ & Students $(\mathbf{N}=\mathbf{6 0})$ \\
\hline \multirow{2}{*}{ Zoom } & $\begin{array}{l}\text { Very easy } n=9 \\
\text { Easy } n=4 \\
\text { Undisclosed } n=2\end{array}$ & $\begin{array}{l}\text { Very easy } n=34 \\
\text { Easy } n=24 \\
\text { Undisclosed } n=2\end{array}$ \\
& Very easy $n=8$ & Very easy $n=17$ \\
Meogle & Easy $n=0$ & Easy $n=13$ \\
& Neutral $n=1$ & Neutral $n=17$ \\
& Not applicable $n=4$ & Not applicable $n=0$ \\
& Undisclosed $n=2$ & Undisclosed $n=13$ \\
Panopto & Very easy $n=0$ & Very easy $n=17$ \\
& Easy $n=1$ & Easy $n=9$ \\
& Neutral $n=4$ & Neutral $n=17$ \\
Not applicable $n=7$ & Not applicable $n=0$ \\
& Undisclosed $n=17$
\end{tabular}

\section{Learning environment and online lectures}

Thirty-four (57\%) students strongly agreed/agreed that the setting at home was adequate to follow online learning activities while 13 (22\%) strongly disagreed/ disagreed and ten (17\%) were neutral. Twenty (38\%) students found that environmental noise from household and neighborhood activities made it difficult to follow online learning activities, while 15 (25\%) were neutral. Technical issues were perceived to affect how well students $(n=23,38 \%)$ could follow online lectures, while ten $(17 \%)$ were neutral.

Table II: Perception of academics ( $\mathrm{N}=15)$ and students $(N=60)$ of online learning

\begin{tabular}{|c|c|c|c|}
\hline Statement & Rating scale & $\begin{array}{c}\text { Academics } \\
\text { (n) }\end{array}$ & $\begin{array}{c}\text { Students } \\
\text { (n) }\end{array}$ \\
\hline $\begin{array}{l}\text { Online learning allowed } \\
\text { more flexibility to my } \\
\text { schedule }\end{array}$ & $\begin{array}{l}\text { Strongly agree } \\
\text { Agree } \\
\text { Neutral } \\
\text { Disagree } \\
\text { Strongly disagree } \\
\text { Not applicable }\end{array}$ & $\begin{array}{l}8 \\
4 \\
1 \\
2 \\
0 \\
0\end{array}$ & $\begin{array}{l}29 \\
17 \\
4 \\
1 \\
2 \\
5\end{array}$ \\
\hline $\begin{array}{l}\text { Online lectures were } \\
\text { more engaging than the } \\
\text { traditional } \\
\text { classroom-based } \\
\text { learning experience }\end{array}$ & $\begin{array}{l}\text { Strongly agree } \\
\text { Agree } \\
\text { Neutral } \\
\text { Disagree } \\
\text { Strongly disagree } \\
\text { Not applicable }\end{array}$ & $\begin{array}{l}0 \\
2 \\
5 \\
2 \\
3 \\
3\end{array}$ & $\begin{array}{l}7 \\
7 \\
14 \\
16 \\
8 \\
7\end{array}$ \\
\hline $\begin{array}{l}\text { Online tutorials were } \\
\text { more engaging than the } \\
\text { traditional } \\
\text { classroom-based } \\
\text { learning experience }\end{array}$ & $\begin{array}{l}\text { Strongly agree } \\
\text { Agree } \\
\text { Neutral } \\
\text { Disagree } \\
\text { Strongly disagree } \\
\text { Not applicable }\end{array}$ & $\begin{array}{l}0 \\
6 \\
2 \\
3 \\
2 \\
2\end{array}$ & $\begin{array}{l}6 \\
5 \\
18 \\
12 \\
9 \\
9\end{array}$ \\
\hline $\begin{array}{l}\text { I prefer lectures } \\
\text { conducted in a } \\
\text { classroom setting }\end{array}$ & $\begin{array}{l}\text { Strongly agree } \\
\text { Agree } \\
\text { Neutral } \\
\text { Disagree } \\
\text { Strongly disagree } \\
\text { Not applicable }\end{array}$ & $\begin{array}{l}3 \\
1 \\
5 \\
4 \\
0 \\
2\end{array}$ & $\begin{array}{l}10 \\
18 \\
9 \\
9 \\
10 \\
3\end{array}$ \\
\hline $\begin{array}{l}\text { I prefer tutorials } \\
\text { conducted in a } \\
\text { classroom setting }\end{array}$ & $\begin{array}{l}\text { Strongly agree } \\
\text { Agree } \\
\text { Neutral } \\
\text { Disagree } \\
\text { Strongly disagree } \\
\text { Not applicable }\end{array}$ & $\begin{array}{l}3 \\
2 \\
6 \\
2 \\
2 \\
0\end{array}$ & $\begin{array}{l}10 \\
12 \\
13 \\
11 \\
8 \\
5\end{array}$ \\
\hline
\end{tabular}

Forty-one (68\%) students felt that the presentations used for the delivery of lectures made it easy to follow lectures online and that the delivery was clear $(n=41,68 \%)$. Twenty-one (35\%) students thought that online lectures were as interactive as lectures conducted in a classroom setting, 25 (42\%) strongly disagreed/disagreed and nine (15\%) were neutral. Twenty-six (43\%) students stated that 
online learning activities were challenging when the aggregate activity spanned beyond three hours, six (10\%) disagreed and ten (17\%) were neutral. Sixteen (27\%) students strongly agreed/agreed that online lectures made it possible to ask questions privately, 16 (27\%) strongly disagreed/disagreed and 16 (27\%) were neutral.

Online tutorials were deemed to be as interactive as tutorials conducted in a classroom setting by 18 (30\%) students, while 23 (38\%) students strongly disagreed and disagreed with this statement and nine (15\%) were neutral. Six (40\%) academics perceive that online teaching affected the delivery of their lectures. Participants were asked whether online learning allowed more flexibility to their schedule, if online lectures and tutorials were more engaging than the traditional classroom-based learning experience and if they prefer lectures and tutorials conducted in a classroom setting (Table II).

\section{Psychological and social aspect of online learning}

The psychological and social effects of online learning on academics and students was evaluated. Seven (47\%) academics perceived the transition from a classroom setting to online as being stressful. The possibility of technical problems occurring during a lecture made five (33\%) academics feel anxious while two (13\%) were neutral. Two (13\%) academics and nine (15\%) students stated that adaptation to online lectures made them feel anxious, while six (40\%) academics and $11(18 \%)$ students were neutral. Ten (67\%) academics and $38(63 \%)$ students agreed/strongly agreed that they missed the social interaction experienced in a classroom setting. Seven (47\%) academics and 36 (60\%) students agreed/strongly agreed that they prefer the social interaction experienced in a classroom setting compared to online lectures. Two (13\%) academics and seven (12\%) students agreed/ strongly agreed that not conducting/attending lectures/ tutorials in a classroom setting made them feel anxious. Three (20\%) academics and ten (17\%) students were neutral. When asked whether online lectures affected their motivation, three (20\%) academics and 29 (48\%) students answered in the affirmative while two (13\%) academics and 11 (18\%) were neutral.

Students strongly agreed/agreed that not attending lectures or tutorials in a classroom setting made them feel lonely $(n=11,18 \%)$ and depressed $(n=9,15 \%)$. Online learning made 26 (43\%) students feel less motivated, while 27 (45\%) participants strongly disagreed/disagreed with this statement.

\section{Future perspectives}

Academics and students were asked for their views regarding future planning for online platforms or hybrid models (Table III). If given the choice, participants strongly agreed/agreed that they would prefer a hybrid approach for lectures (academics $n=10,67 \%$; students $n=39,65 \%$ ) and tutorials (academics $n=11,73 \%$; students $n=36,60 \%$ ).

Table III: Preferences to switch lectures and tutorials to online platforms for academics ( $N=15)$ and students ( $N=60)$

\begin{tabular}{|c|c|c|c|}
\hline Statement & Rating scale & $\begin{array}{c}\text { Academics } \\
\text { (n) }\end{array}$ & $\begin{array}{c}\text { Students } \\
\text { (n) }\end{array}$ \\
\hline $\begin{array}{l}\text { If given the choice I } \\
\text { would prefer to } \\
\text { switch all lectures to } \\
\text { online platforms }\end{array}$ & $\begin{array}{l}\text { Strongly agree } \\
\text { Agree } \\
\text { Neutral } \\
\text { Disagree } \\
\text { Strongly disagree } \\
\text { Not applicable }\end{array}$ & $\begin{array}{l}1 \\
4 \\
2 \\
3 \\
2 \\
3\end{array}$ & $\begin{array}{l}16 \\
8 \\
9 \\
10 \\
12 \\
4\end{array}$ \\
\hline $\begin{array}{l}\text { If given the choice I } \\
\text { would prefer to } \\
\text { switch all tutorials to } \\
\text { online platforms }\end{array}$ & $\begin{array}{l}\text { Strongly agree } \\
\text { Agree } \\
\text { Neutral } \\
\text { Disagree } \\
\text { Strongly disagree } \\
\text { Not applicable }\end{array}$ & $\begin{array}{l}4 \\
5 \\
2 \\
3 \\
1 \\
0\end{array}$ & $\begin{array}{l}13 \\
6 \\
14 \\
9 \\
9 \\
8\end{array}$ \\
\hline $\begin{array}{l}\text { If given the choice I } \\
\text { would prefer to use } \\
\text { a hybrid approach } \\
\text { for lectures whereby } \\
\text { some of the lectures } \\
\text { are switched to } \\
\text { online platforms }\end{array}$ & $\begin{array}{l}\text { Strongly agree } \\
\text { Agree } \\
\text { Neutral } \\
\text { Disagree } \\
\text { Strongly disagree } \\
\text { Not applicable }\end{array}$ & $\begin{array}{l}5 \\
5 \\
3 \\
1 \\
0 \\
1\end{array}$ & $\begin{array}{l}24 \\
15 \\
10 \\
6 \\
3 \\
1\end{array}$ \\
\hline $\begin{array}{l}\text { If given the choice I } \\
\text { would prefer to use } \\
\text { a hybrid approach } \\
\text { for tutorials whereby } \\
\text { some tutorials are } \\
\text { switched to online } \\
\text { platforms }\end{array}$ & $\begin{array}{l}\text { Strongly agree } \\
\text { Agree } \\
\text { Neutral } \\
\text { Disagree } \\
\text { Strongly disagree } \\
\text { Not applicable }\end{array}$ & $\begin{array}{l}6 \\
5 \\
3 \\
1 \\
0 \\
0\end{array}$ & $\begin{array}{l}19 \\
17 \\
8 \\
5 \\
4 \\
4\end{array}$ \\
\hline
\end{tabular}

Participants were asked if they had any further comments regarding online learning. Comments included that advantages associated with online lectures included flexibility ( $n=1,7 \%)$ and the ability of students to view recorded lectures at any time should they be sick or wish to view a lecture again ( $n=4,7 \%)$. Students found that online lectures were as effective as in a classroom setting $(n=3,5 \%)$ and that it enabled them to focus better than when in the classroom $(n=1,2 \%)$. They also stated that it saved time, as it eliminates the need to commute to the University campus, especially when they only have two hours of lectures on a particular day and avoids hassle related to parking and weather conditions $(n=7,12 \%)$. 
One $(7 \%)$ academic argued that having remote lectures is convenient especially when the lecturer is away on conferences, and that way, the timetable would not be disrupted. One (7\%) respondent argued that a hybrid approach is only appropriate with small groups because with larger groups, it becomes impersonal. Another respondent (7\%) said that with the remote learning, students will be more attentive since chit chat is not possible.

However, students also commented that they feel that clinical skills and practice activities $(n=1,2 \%)$ and lectures requiring interaction in class $(n=3,5 \%)$ should be conducted in a classroom setting. One (2\%) student commented that long lectures should be conducted online and short lectures in a classroom setting, while another (2\%) stated that lectures longer than one hour can be distracting at home, especially if the internet connection is slow.

\section{Discussion}

Although the transition from a classroom-based approach to an online environment took place rapidly and, in a few weeks, adaptation to the new teaching and learning environment was perceived to be easy and participants had the required technology to support this change. Although participants in this study had the required technology, other studies showed that access to technology and internet service was a challenge due to financial issues (Li \& Irby, 2008; Shahmoradi, 2018). The smooth shift to an online environment may have been attributed to the support given by administration, academics and the University to the concerned parties and the motivation by all stakeholders to overcome the challenging times. The shift from the traditional class-based teaching setting to an online environment can be challenging when teaching since the pedagogical approach needs to be adapted for online teaching (Dhawan, 2020). Another factor which contributes to a smooth shift to online learning is technology-related knowledge. Studies found different levels of preparedness and knowledge related to technology for online learning amongst students (Hung et al., 2010; Parkes, Stein \& Reading, 2015; Kim, Hong \& Song, 2019; Mokaripour, Shokrpour \& Bazrafkan, 2020).

Participants stated that online lectures were not more engaging or as interactive as classroom-based lectures. Interaction between the student and teacher is a crucial aspect in the learning process since it engages students during lectures, stimulates discussion and promotes critical thinking (Banna et al., 2016). A study found that students valued real-time interaction during synchronous online sessions (Banna et al., 2016). For future developments, aspects that may be considered to enrich the experience include use of animations and quizzes which was reported to improve the interaction and engagement of students during online learning (Morton et al., 2016). Course design is an important aspect which promotes student engagement such as by promoting interaction (Banna et al., 2016). Another approach which may improve student engagement and interaction includes the strategic planning of online activities by ensuring that the aggregate activities are no longer than three hours, since students perceived the duration of lectures to affect online learning. This is especially relevant when the majority of the teaching was conducted as synchronous remote teaching. The use of synchronous online teaching offers advantages such as increased interaction and real-time communication (McBrien, Rui \& Jones, 2009; Dhawan, 2020), however it lacks the flexibility offered by asynchronous online teaching (Banna et al., 2018).

Although the transition and adaptation to online learning was perceived to be easy by participants, a minority of students and academics felt that this shift affected them psychologically. This finding is in accordance with other studies which found that some students experience anxiety when conducting an online course (Kohan et al., 2017; Saadé et al., 2017). This is worth noting since providing education within a healthcare profession, pharmacy educators need to take into account the impact on all ends of the spectrum. Participants missed the social interaction aspect of attending classroom-based lectures and as a result, the lack of face-to-face interaction may have led to some students and academics feeling anxious, lonely and depressed. Uncertainties brought about by the pandemic and adjustment to the new norm may have also contributed to the anxiety level (Daniel, 2020; Rapanta et al., 2020). Half of the students participating in the study felt that online lectures led to a decrease in motivation. In a study evaluating blended learning, it was observed that students found the modules motivating and that they appreciated the flexibility presented by this approach (Herbert et al., 2017). The lack of motivation should be addressed as it is an important aspect for the implementation of a successful learning approach (Herbert et al., 2017).

When participants were asked regarding future adoption of remote teaching, the majority preferred a hybrid approach. This finding was in accordance with another study by Lean and colleagues (2020). Online teaching can 
be applied as a full transition from a classroom-based approach to an online environment or as a blended learning approach. The blended approach can take place in various forms and has the advantages associated with online teaching, whilst still maintaining the face-to-face interaction (Kabassi et al., 2016; Morton et al., 2016; Herbert et al., 2017), and has a significant potential in higher education (Garrison \& Kanuka, 2004; Kabassi et al., 2016). Blended online learning has been applied in different courses and it has been found to be effective (Crouch, 2009; Morton et al., 2016). This approach can be of particular benefit for modules which deliver theoretical and practical aspects.

Participants in this study also presented various advantages related to online lectures. Online learning can be a good approach to address the problem of traffic and availability of parking spaces at the University of Malta campus since students are not required to be physically present on campus. Attending lectures online eliminates the need for commuting to University which contributes to a decrease in the carbon footprint and pollution caused by traffic (Nelson, 2006; Caird et al., 2015; Versteijlen et al., 2017).

\section{Limitations}

The small sample size might not be representative of the whole population. Another limitation of the study is that the impact of the pandemic on anxiety was not evaluated. Future studies can include the assessment of technologybased knowledge and the evaluation of long-term use of remote learning, the resilience of the system and how it impacts on professional skills set development in pharmacists and pharmaceutical technologists. Areas that would benefit more from the online learning to provide greater opportunity for other learning activities in the face-to-face set up should also be evaluated. The outcomes of this study will be applied for future online teaching and further research will be conducted to evaluate the impact of the intervention on the perception of academics and students.

This study confirmed that overall the sudden shift to remote teaching at the Department of Pharmacy of the University of Malta brought about by the COVID-19 pandemic was handled smoothly and had a minor impact on the academic staff and pharmacy students for the short-term period from March to June 2020. The impact when the model of complete remote teaching is implemented on a longer time frame was not studied.
From this study it transpires that considering a hybrid learning approach is a way forward. Teaching activities which may be transferred to online teaching should be identified and activities where live interaction strengthens the learning process and contributes to professional and soft skills development are to be maximised.

\section{References}

Banna, J., Grace Lin, M.F., Stewart, M., \& Fialkowski, M.K. (2015). Interaction matters: Strategies to promote engaged learning in an online introductory nutrition course. Journal of online learning and teaching, 11(2), 249-261

Caird, S., Lane, A., Swithenby, E., Roy, R., \& Potter S. (2015). Design of higher education teaching models and carbon impacts. International Journal of Sustainability in Higher Education, 16(1), 96-111. https://doi.org/10.1108/IJSHE-06-2013-0065

Crouch, M.A. (2009). An advanced cardiovascular pharmacotherapy course blending online and face-to-face instruction. American Journal of Pharmaceutical Education, 73(3), 51. https://dx.doi.org/10.5688\%2Faj730351

Daniel, S.J. (2020). Education and the COVID-19 pandemic. Prospects, 1-6. Advance online publication. https://doi. org/10.1007/s11125-020-09464-3

Dhawan S. (2020). Online Learning: A Panacea in the Time of COVID-19 Crisis. Journal of Educational Technology Systems, https://doi.org/10.1177/0047239520934018

Garrison, D.R., \& Kanuka, H. (2004). Blended learning: Uncovering its transformative potential in higher education. The Internet and Higher Education, 7(2), 95-105. https://doi.org/10.1016/j.iheduc. $\underline{2004.02 .001}$

Gray, K., \& Tobin, J. (2010). Introducing an online community into a clinical education setting: a pilot study of student and staff engagement and outcomes using blended learning. BMC Medical Education, 10(1), 6. https://doi.org/10.1186/1472-6920-10-6

Grech, V., \& Attard-Montalto, S. (2020). The impact of COVID-19 on the Malta Medical School. Malta Medical School Gazette, 4(1), 5-16

Herbert, C., Velan, G.M., Pryor, W.M., \& Kumar, R.K. (2017). A model for the use of blended learning in large group teaching sessions. BMC Medical Education, 17(1), 197. https://doi.org/10. $\underline{1186 / \mathrm{s} 12909-017-1057-2}$

Hung, M.L., Chou, C., Chen C. H., \& Own, Z.Y. (2010) Learner readiness for online learning: Scale development and student perceptions. Computer and Education, 55(3), 1080-1090. https://doi.org/10.1016/j.compedu.2010.05.004

Jenkins, S., Goel, R., \& Morrell, D.S. (2008). Computer-assisted instruction versus traditional lecture for medical student teaching of dermatology morphology: A randomized control trial. Journal of the American Academy of Dermatology, 59(2), 255-259. https://doi.org/10.1016/i.jaad.2008.04.026 
Kabassi, K., Dragonas, I., Ntouzevits, A., Pomonis, T., Papastathopoulos, G., \& Vozaitis, Y. (2016). Evaluating a learning management system for blended learning in Greek higher education. SpringerPlus, 5(1), 101. https://dx.doi.org/10. $\underline{1186 \% 2 F s 40064-016-1705-8}$

Kahl, T.N., \& Cropley, A.J. (1986). Face-to-face versus distance learning: psychological consequences and practical implications. Distance Education, 7(1), 38-48. https://doi.org/10.1080/015879 1860070104

Kim, H.J., Hong, A.J. \& Song, H. (2019). The roles of academic engagement and digital readiness in students' achievements in university e-learning environments. International Journal of Educational Technology in Higher Education, 16, 21. https://doi.org/10.1186/s41239-019-0152-3

Kohan, N., Soltani Arabshahi, K., Mojtahedzadeh, R., Abbaszadeh, A., Rakhshani, T., \& Emami, A. (2017). Self- directed learning barriers in a virtual environment: a qualitative study. Journal of advances in medical education \& professionalism, 5(3), 116-123

Lean, Q. Y., Ming, L. C., Wong, Y.Y., Neoh, C.F., Farooqui, M., \& Fadzilah Muhsain, S.N. (2020). Online versus classroom learning in pharmacy education: Students' preference and readiness. Pharmacy Education, 20(1), 19-27

Li, C.-S., \& Irby, B. (2008). An Overview of Online Education: Attractiveness, Benefits, Challenges, Concerns and Recommendations. College Student Journal, 42(2), 449-458

McBrien, J.L., Chen, R., \& Jones, P. (2009). Virtual Spaces: Employing a synchronous online classroom to facilitate student engagement in online learning. International Revie of Research in Open and Distance Learning, 10(3). https://doi.org/10.19173/ irrodl.v10i3.605

McFarlin, B.K. (2008). Hybrid lecture-online format increases student grades in an undergraduate exercise physiology course at a large urban university. Advances in Physiology Education, 32(1), 86-91. https://doi.org/10.1152/advan.00066.2007

Mokaripour, P., Shokrpour, N., \& Bazrafkan, L. (2020). Comparison of readiness for e-learning from the perspective of students and professors of Medical Sciences. Journal of Education and Health Promotion, 9, 111. https://doi.org/10.4103/jehp.jehp 66819

Morton, C.E., Saleh, S.N., Smith, S.F., Hemani, A., Ameen, A., Bennie, T.D., \& Toro-Troconis, M. (2016). Blended learning: How can we optimise undergraduate student engagement? $B M C$ Medical Education. 16,195. https://doi.org/10.1186/s12909016-0716-z

Nelson, O.N. (2006). Factors of online learning adoption: A comparative juxtaposition of the theory of planned behaviour and the technology acceptance model. International Journal on ELearning, 5(4), 571-591

Parkes, M., Stein, S., \& Reading, C. (2015). Student preparedness for university e-learning environments. The Internet and Higher Education, 25,1-10. https://doi.org/10.1016/j.iheduc.2014.10.002

Rapanta, C., Botturi, L., Goodyear, P., Guàrdia, L., \& Koole, M. (2020). Online University Teaching During and After the Covid-19 Crisis: Refocusing Teacher Presence and Learning Activity. Postdigital Science Education, 1-23. https://doi.org/10. 1007/s42438-020-00155-y
Saadé, R.G., Kira, D., Mak, T., \& Nebebe, F. (2017). Anxiety and Performance in Online Learning. In Proceedings of the Informing Science and Information Technology Education Conference, Vietnam, Santa Rosa, CA: Informing Science Institute., pp.147-157. https://doi.org/10.28945/3736

Shahmoradi, L., Changizi, V., Mehraeen, E., Bashiri, A., Jannat, B., \& Hosseini, M. (2018). The challenges of E-learning system: Higher educational institutions perspective. Journal of Education and Health Promotion, 7,16. https://dx.doi.org/10.4103\%2Fiehp. jehp 3918

Versteijlen, M., Perez Salgado, F., Janssen Groesbeek, M., \& Counotte, A. (2017). Pros and cons of online education as a measure to reduce carbon emissions in higher education in the Netherlands. Current Opinion in Environmental Sustainability, 28, 80-89. https://doi.org/10.1016/i.cosust.2017.09.004

Yeh, Y.-T., Chen, H.-Y., Cheng, K.-J., Hou, S.-A., Yen, Y.-H., \& Liu, C.-T. (2014). Evaluating an online pharmaceutical education system for pharmacy interns in critical care settings. Computer Methods and Programs in Biomedicine, 113(2), 682-689. https://doi.org/10.1016/i.cmpb.2013.11.006 